\title{
Şairi bilinmeyen bir Siroz şehrengizi ${ }^{1}$
}

Derya KARACA²

\begin{abstract}
APA: Karaca, D. (2019). Şairi bilinmeyen bir Siroz şehrengizi. RumeliDE Dil ve Edebiyat Araştırmaları Dergisi, (16), 428-444. DOI: 10.29000/rumelide.618985
\end{abstract}

\section{Öz}

Klasik Türk şiirinde Rumeli, hem coğrafyası hem de yetiştirdiği sayısız şairle geniş ve önemli bir yere sahiptir. Kendine has şiir anlayışı ve özelliğine sahip olan Rumelili şairlerin, klasik Türk şiirine birçok katkısı olmuştur. Edebiyatımızda XVI. yüzyılda ortaya çıkan XVIII. yüzyılın sonlarına kadar devam eden, bir şehrin güzellikleri ile daha çok çarşı esnafından erkek güzellerini anlatan şehrengiz türünün ilk örneği, Rumelili şairlerden Priştineli Mesîhî tarafından Edirne hakkında yazılmıştır. Mesîhî’den sonra birçok şair, çeşitli şehirler hakkında şehrengiz kaleme almıştır. Osmanlı Devleti’ne başkentlik yapan Bursa, Edirne, İstanbul başta olmak üzere sosyo-kültürel ve ekonomik açıdan önemli bir yere sahip olan Abkır, Belgrad, Gümülcine, İştip, Moton, Mostar, Rodos, Siroz, Üsküp, Yenice, Yenişehir gibi Rumeli şehirleri adına da şehrengiz yazılmıştır. Bunlardan Osmanlı Devleti'nin Rumeli'deki önemli kültür ve ticaret merkezlerinden biri olan Siroz hakkında yazllan iki şehrengizden biri, XVI. yüzyll şairlerinden Defterdâr-zâde Ahmed Cemâlî’ye aittir. Diğer Siroz şehrengizinin ise müellifi bilinmemektedir. Eserin bilinen tek nüshası, İstanbul Üniversitesi Kütüphanesi TY 818 (v. 74a78b)'de kayıtlıdır. 28 güzelin üçer beyitle tasvir edildiği şehrengiz, mesnevi nazım şekliyle yazılmış olup 105 beyitten ibarettir. İçerisinde şehir tasviri bulunmayan Siroz Şehrengizi’nde, güzeller tasvirine ağırlık verilmiştir. Bu makalede, şairi bilinmeyen "Şehr-engîz-i Siroz"un muhteva incelemesi yapılarak transkripsiyonlu metni verilmiştir.

Anahtar kelimeler: Siroz, şehrengiz, şehir, Rumeli, klasik Türk şiiri.

\section{A shehrengiz of Siroz by an unknown poet}

\begin{abstract}
Rumelia occupies a vast and important place in classical Turkish poetry both due to its geography and the numerous poets raised there. With their unique understanding and characteristic of poetry, Rumelian poets have contributed greatly to classic Turkish poetry. Şehrengiz is a genre of poetry that first emerged in Ottoman literature in the 16th century and continued its existence until the 18th century. The genre is written in honor of the beauties of a city and particularly the beautiful young men of the guilds. The first of its kind was written by Rumelian poet Priştineli Mesîhî for Edirne province. Following Mesîhî, many poets have written şehrengiz poems to honor various cities. Rumelian cities such as Abkır, Belgrade, Komotini, Shtip, Moton, Mostar, Rhodes, Siroz (Sérres), Skopje, Yenice, Yenişehir and particularly Bursa, Edirne and Istanbul, all of which served as capitals of the Ottoman State in various periods and had socio-cultural and economic importance, were among the cities about which şehrengiz poems were written. One of two şehrengiz poems about Siroz, an Ottoman center of culture and trade in Rumelia, was written by Defterdâr-zâde Ahmed Cemâlî, a
\end{abstract}

Bu çalışma, 06-09 Aralık 2018 tarihlerinde Ankara'da düzenlenen Uluslararası İnsan Çalışmaları Kongresi'nde sözlü bildiri olarak sunulmuştur.

Dr. Öğr. Üyesi, Iğdır Üniversitesi, Fen-Edebiyat Fakültesi, Türk Dili ve Edebiyatı Bölümü (Iğdır/Türkiye), drykaraca86@gmail.com, ORCID ID: 00oo-0003-3124-5978 [Makale kayt tarihi: 06.08.2019-kabul tarihi:20.09.2019; DOI: $10.29000 /$ rumelide.618985] 


\begin{abstract}
poet who lived in the 16th century. The author of the other şehrengiz is not known. The only known copy of the work is registered at Istanbul University Library with number TY 818 (v. 74a-78b). This şehrengiz, in which 28 beautiful young men of the guilds are depicted, each in three couplets, is written in the mathnawi poetic form, and consists of 105 couplets in total. The focus of this work, which contains no city depiction, focuses on the depiction of beautiful young men. This article presents a content review of the "Şehr-engîz-i Siroz", the author of which is unknown, along with its transcribed text.
\end{abstract}

Keywords: Siroz (Sérres), shehrengiz, city, Rumelia, classical Turkish poetry.

\title{
Giriş
}

Rumeli, Osmanlı Devleti’nin Balkan yarımadasına verdiği coğrafî isim ve bu bölgeyi içine alan eyalete denilmektedir. Bizanslıların kendileri ve ülkeleri için kullandıkları Romaioi, Romania kelimeleri İslâm dünyasında onların Rum, Doğu Roma İmparatorluğu ülkesinin de "bilâdü’r-Rûm" veya "memleketü’rRûm" şeklinde tanınmasına yol açmış, bu tabirler, Anadolu'nun Türk-İslâm hâkimiyeti altına girmesinden sonra Rum ismiyle Bizans idaresinde bulunmuş Anadolu’yu gösteren bir coğrafî ad olarak yaygınlaşmıştır. Batılı seyyahlar, XIII. yüzyılda Türkler'in idaresindeki Anadolu'ya Turquemenie (Turquie) ve Bizans İmparatorluğu'na tâbi yerlere Romanie (Romania) diyorlardı. Nihayet bu tabir, daha ziyade Ortodoks Yunan mezhebinin hâkim bulunduğu Balkan yarımadasını ifade etmeye başladı. Osmanlı Türkleri, Balkanlar için Rum-ili adını Romania'dan aldılar ve Anadolu’ya karşı denizin ötesinde Bizanslılar'dan fethettikleri bölgeler için kullandılar (İnalcık, 2008: 232). Yani Osmanlı'nın Avrupa'da fethettiği Trakya'dan Balkanlara kadar uzanan bölge, Rumeli olarak bilinmektedir. Rumeli'ye bazen Balkanlar da denilir. Fetih hareketlerine bağlı olarak Rumeli'nin sınırları sürekli değişmiş, XVII. yüzyıldan itibaren ise sınırlar daralmaya başlamış ve Balkan Savaşları'ndan sonra Rumeli'deki topraklarımız, bugünkü sınırlara gelmiştir (Çeltik, 2009: 805).

Osmanlı'nın Avrupa'daki kısmı olan ve Rum-ili (Rumeli) olarak da zikredilen Balkanlar'ın fethi ve iskânıyla birlikte, Edirne, Gelibolu, Saraybosna, Siroz (Serez), Vardar Yenicesi, Üsküp, Manastır, Filibe, Selânik, Sofya ve Belgrad gibi şehirler, kısa sürede önemli birer kültür ve sanat merkezi olarak değer kazanır (Çeltik, 2009: 805). Rumeli'nin kültürel açıdan ne denli gelişmiş olduğu Âşık Çelebi’nin,
"Rivayet olunur ki Prizren'de oglan dogsa, adından mukaddem mahlas korlar. Yenice'de dogan oglan, etmege papa diyecek vakt Fârsî söyler. Priştine'de oglan dogsa, diviti belinde doğar dirler. Binâ'en- 'alâ-zâlik, Prizren şâir menbaı ve Yenice Fârsî ocagı ve Piriştine kâtib yatağıdur.” (2010: II/904)

sözleri açılklamaktadır. Rumeli şairleri, "Rumeli coğrafyasını işleme, şehrengiz türünü icat etme, hece vezniyle şiir yazmayı başlatma ile gerçek sevgili ve âşık tiplerini ele alma” gibi bazı noktalarda klasik Türk edebiyatına yeni bir yön vermiş ve önemli katkılar sağlamışlardır (Çeltik, 2009: 806).

Şehrengiz, klasik Türk edebiyatında XVI. yüzyılda ortaya çıkan, XVIII. yüzyılda sona eren bir şehrin güzellikleri ile daha çok güzellerini anlatan manzum bir edebi tür olup ilk örneği, Priştineli Mesîhî tarafından Edirne hakkında yazılmıştır. Edebiyatımızda şehrengizler gazel, terkib-i bend, muhammes gibi farklı nazım şekilleriyle yazılmakla birlikte çoğunlukla mesnevi nazım şekliyle aruzun "Mefâ̂ilün/Mefâ̂îü/Féûlün" kalıbıyla kaleme alınmıştır. Şehrengizler genellikle münacat bölümüyle başlar, daha sonra sebeb-i telif, şehir tasviri ve asıl konunun işlendiği bölüm (güzeller tasviri) ile devam eder ve hatime bölümüyle sona erer. Şehrengizin münacat bölümünde şair, namaz oruç gibi kulluk görevlerini yerine getirmeyip güzellerin peşinden koştuğunu söyleyerek pişmanlığını dile getirir ve 
Allah'tan kendisini affetmesini ister. Şehrengizi yazma sebebini açıladığı sebeb-i telif bölümünden sonra şair, şehir tasviri bölümüne geçer ve şehrin genel, coğrafi, tarihî, mimari özellikleri ile şehir halkının özelliklerini anlatır. Şehrengizin güzeller tasviri bölümünde ise şair, şehrin güzellerini meslek, isim, lakapları etrafinda tasvir eder ve güzellere hayır duasında bulunduğu hatime bölümüyle eserini tamamlar. Şehrengizlerdeki güzellerin çoğunluğu esnaf sınıfından erkekler olup sadece Azîzînin İstanbul şehrengizinde 50 kadın güzel anlatılmıştır (Karaca, 2018b: 1-2, 4-5, 9, 20-21). Şehrengizlerde şairler, doğup büyüdükleri, bir süre yaşadıkları veya gördükleri şehirleri, doğal, tarihî, mimari güzellikleri ve güzelleriyle şiirlerinde anlatırlar.

Klasik Türk şiirinde şehrengiz, Mesîhî̀den sonra çok rağbet görmüş ve birçok şair tarafından çeşitli şehirler hakkında şehrengiz yazılmıştır: Zâtî, Edirne3 (1512); Kâtib, İstanbul ve Vize4 (1513); Taşlıcalı Yahyâ, İstanbul5 ve Edirne ${ }^{6}$ (1523'den sonra); Lâmi'î, Bursa7 (1523'den sonra); Hayretî, Belgrad ${ }^{8}$ ve Yenice9 (1521'den sonra) gibi. Mevcut bilgilere göre XVI. yüzyılda 58, XVII. Yüzyılda 10, XVIII. yüzyılda 7 şehrengiz kaleme alınmıştır. Bunlar dışında ayrıca şehrengiz özelliği taşıyan eserler de bulunmaktadır: Tâcî-zâde Cafer Çelebi'nin Heves-nâme ${ }^{10}$; Enderunlu Fazıl'ın Defter-i Aşk ${ }^{11}$, Hûbân-nâme, Zenânnâme' ${ }^{12}$, Çengi-nâme ${ }^{13}$ gibi (Karaca, 2018b: 13-20). Bu eserlerle birlikte edebiyatımızdaki şehrengiz sayısı 92'ye çıkmaktadır. Hangi şehre yazıldığı bilinmeyen şehrengizler olmakla birlikte mevcut bilgilere göre 31 ayrı şehir hakkında yazılan bu 92 şehrengiz ve şehrengiz benzeri eserin 22'sinde 14 Rumeli şehri14 konu edilmektedir:

\begin{tabular}{|c|c|c|c|}
\hline Şehir Adı & Müellifi & Telif Tarihi & Şehrengiz Adı \\
\hline Abkır & Za'fî-i Gülşenî & 16. yy & Şehr-engîz-i Âbkur ${ }^{15}$ \\
\hline Belgrad & Hayretî & $\begin{array}{l}\text { 1521'den } \\
\text { sonra }\end{array}$ & Şehr-engîz-i Belgrad ${ }^{16}$ \\
\hline Gümülcine & Dürrî & 17. yy & Şehr-engîz-i Gümülcine ${ }^{17}$ \\
\hline İştip & Za'fî-i Gülşenî & 1540 & Şehr-engîz-i Şehr-i İștife ${ }^{18}$ \\
\hline
\end{tabular}

Derya Karaca (2018a), “Zâtî’nin Edirne Şehrengizi”, Uluslararası Sosyal Araştırmalar Dergisi/The Journal of International Social Research, Şubat, C. 11, S. 55, s. 114-136.

$4 \quad$ Hasan Kaya (2015), "Kâtib Davud'un İstanbul ve Vize Şehrengizi", Turkish Studies-International Periodical For The Languages, Literature and History of Turkish or Turkic,, Volume 10/12, Summer, s.631-686.

5 Mehmed Çavuşoğlu (1969), "Taşlıcalı Dukakin-zade Yahya Bey’in İstanbul Şehrengizi”, Türk Dili ve Edebiyatı Dergisi, Ağustos 1969, C.XVII, s.73-108

6 Mehmed, Çavuşoğlu (1977), "Şehrengiz-i Edirne”, Yahya Bey: Divan, İstanbul Üniversitesi Edebiyat Fakültesi Yay., İstanbul, s. 227-243.

7 Mustafa İsen, H. B. Burmaoğlu (2011). Bursa Şehrengizi (Lâmiî Çelebi), Bursa Büyükşehir Belediyesi Yay., Bursa; Nuran Tezcan (2001), "Güzele Bir Şehrengizden Bakış”, Türkoloji Dergisi, C.I, (XI), s. 161-194.

8 Mehmed Çavuşoğlu (1973-1974), "Hayreti’nin Belgrad Şehrengizi”, Güney-Doğu Avrupa Araşttrmaları Dergisi, C.II-III, s.325-356.

9 Mehmed Çavuşoğlu (1975-1976), "Hayreti’nin Yenice Şehrengizi”, Güney-Doğu Avrupa Araştırmaları Dergisi, C.IV-V, s. 81-100.

$10 \quad$ Necati Sungur (2006), Tâcî-zâde Cafer Celebi, Heves-nâme (İnceleme-Tenkitli Metin), TDK Yay., Ankara

11 Selim S. Kuru (2005), "Biçimin Kıskacında Bir ‘Tarih-i Nev-icad’: Enderunlu Fazıl Bey ve Defter-i Aşk Adlı Mesnevisi”, A. Festschift For Şinasi Tekin, Haz. Günay Kut- Fatma Büyükkarcı Yılmaz, İstanbul: Simurg Yay., s. 476-506.

Nebiye Öztürk (2002), Zenânnâme Enderûnlu Fâzl, Yüksek Lisans Tezi, İstanbul Üniversitesi, Sosyal Bilimler Enstitüsü, Türk Dili ve Edebiyatı Ana Bilim Dalı, İstanbul.

3 Barıș Karacasu (2006), “'Bize Çengîleri Kıl Rûșen ü Pâk ya da 'Hayra Hezlin Dahi Bir Rehberi Var”, Osmanlı Araștırmaları Dergisi (Prof. Dr. Mehmed Çavuşoğlu'na Armağan III), S.27, s.133-160.

Osmanlı Devleti'nin bugünkü Türkiye sınırları dışında kalan Rumeli şehirleri dâhil edilmiştir.

Abdurrahman Adak (2006), "Za'fî-i Gülşenî Hayatı, Eserleri, Edebî Şahsiyeti ve Dîvânının İncelenmesi”, Doktora Tezi, Ankara Üniversitesi, Sosyal Bilimler Enstitüsü, Ankara; Zehra Göre (2015), "Za’fî-i Gülşenî’nin Moton Şehrengizi”, Osmanh Mirası Araştırmaları Dergisi (OMAD), C. 2, (4), Kasım, s. 41-57.

16 Bk. Çavuşoğlu, 1973-1974: 325-356.

17 İlyas Yazar (2007), "Dürri’nin Şehregizinden Gümülcine’ye Bakış”, Turkish Studies/Türkoloji Araşttrmaları, Volume 2/2 Spring., s. 770-789.

18 Bilal Çakıcı (2010), "The Shahrangiz of Shtip by Za'fi”, International Journal of Central Asian Studies, Volume 14, Korea, s. 95-107. 


\begin{tabular}{|c|c|c|c|}
\hline & Maksadî & 16. yy & Şehr-engîz-i İştip ${ }^{19}$ \\
\hline Kara Ferye & Garâmî & 16. yy & Şehr-engîz-i Kara Ferye ${ }^{20}$ \\
\hline Mostar & Hacı Derviş & $1630-31$ & Şehr-engîz-i Mostar ${ }^{21}$ \\
\hline \multirow[t]{2}{*}{ Moton } & Za'fî-i Gülşenî & 16. yy & Şehr-engîz-i Moton ${ }^{22}$ \\
\hline & Dürrî & 17. yy & $\begin{array}{l}\text { Şehr-i Motona İrsâl } \text { Olunan Şehr- } \\
\text { engîzdür }{ }^{23}\end{array}$ \\
\hline $\begin{array}{l}\text { Podgorica } \\
\text { İşkodra }\end{array}$ & Cem’î̀ 24 & 19. yy & - \\
\hline Rodos & Sânî & 16. yy & Şehr-engîz-i Rodos ${ }^{25}$ \\
\hline \multirow[t]{2}{*}{ Siroz } & Defterdâr-zâde Ahmed Cemâlî & 16. yy & Şehr-engîz-i Sîroz ${ }^{26}$ \\
\hline & Adı Bilinmeyen Şair & $?$ & Şehr-engîz-i Siroz \\
\hline Üsküp & Üsküplü İshâk Çelebi & 16. yy & Şehrengîz-i Mahbûbân-ı Vilâyet-i Üsküb ${ }^{27}$ \\
\hline \multirow[t]{4}{*}{ Yenice } & Hayretî & 16. yy & Şehr-engîz-i Yenice ${ }^{28}$ \\
\hline & Usûlî & 16. yy & Şehrengiz-i Yenice ${ }^{29}$ \\
\hline & Za'fî-i Gülşenî & 16. yy & Şehr-engîz-i Şehr-i Yenice-i Vardar3o \\
\hline & Maksadî & 16. yy & Şehr-engîz-i Yenice ${ }^{31}$ \\
\hline \multirow[t]{3}{*}{ Yenişehir } & Bursalı Rahmî & 16. yy & $\begin{array}{l}\text { Sehr-engîz-i Yeni-şehr } \quad \text { Rahmî } \quad \text { Efendi } \\
\text { Fermâyed }{ }^{2}\end{array}$ \\
\hline & Vahîd Mahtûmî & 18. yy & Lâle-zâr (Yenişehr-i Fenâr Şehrengizi)33 \\
\hline & Yenişehirli Avnî Bey & 19. yy & Der-Vasf-ı Yenişehr-i Fenâr34 \\
\hline
\end{tabular}

Tablo 1: Rumeli Şehrengizleri

19 Murat Öztürk (2014), "Maksadi’nin Yenice ve İştip (İştib) Şehrengizleri”, Mustafa Kemal Üniversitesi Sosyal Bilimler Enstitüsü Dergisi, C.11, (25), s. 51-80.

$20 \quad$ Âsık Celebi (2010), Mesa'irü’s-Su'arâ, Haz. Filiz Kılıç, 3 Cilt İstanbul: İstanbul Araștırmaları Enstitüsü Yayınevi, s.1628.

21 Beyhan Kesik (2010), "Yeni Bir Nüshadan Hareketle Hacı Derviş’in Mostar Şehrengizi”, Turkish Studies, Volume 5/3, Summer, s. 368-399.

22 Zehra Göre (2015), "Za’fî-i Gülșenî’nin Moton Șehrengizi”, Osmanh Mirası Araştırmaları Dergisi (OMAD), C. 2, (4), Kasim, s. 41-57.

İlyas Yazar (2009), “Dürrî’nin Moton Șehr-engîzi”, Erdem Dergisi, (55), s. 175-190.

24 Cem’̂̀’nin Destan-ı Karadağ adlı eseri içinde Podgorica ve İșkodra șehirlerini anlatan bazı bölümler bulunmaktadır. Bu bölümler şehrengiz özelliği taşımaktadır (Çă̆layan, 2013).

25 Yasar Aydemir (2001), "Sani'nin Rodos Sehrengizi”, Türk Kültürü, S. 455, s.167-174.

26 Lokman Turan (2011). "Defterdâr-zâde Ảhmed Cemâli’nnin Siroz Şehrengizi”, İSAM Osmanlı Araştırmaları, S. XXXVII, s. 49-76.

$27 \quad$ Metin Akkus (1987), Türk Edebiyatında Sehr-engîzler ve Bursa Sehr-engîzleri, Yüksek Lisans Tezi, Atatürk Üniversitesi, Sosyal Bilimler Enstitüsü, Türk Dili ve Edebiyatı Ana Bilim Dal,, Erzurum; Murat Keklik (2014), Üsküplü İshâk Çelebi Divan (Metin-Ceviri-Açıklamalar-Dizin), Doktora Tezi, Kırgızistan-Türkiye Manas Üniversitesi, Sosyal Bilimler Enstitüsü, Türkoloji Ana Bilim Dalı, Bişkek.

28 Bk. Çavuşoğlu, 1975-1976: 81-100

29 Mustafa İ̀en (1988), "Usuli'nin Yenice Sehrengizi", Türk Kültürü Arasttrmaları (Mehmed Kaplan İçin), s.131-148; Mustafa İsen (1997), “Usuli’nin Yenice Şehrengizi”, Ötelerden Bir Ses Divan Edebiyatı ve Balkanlarda Türk Edebiyatı Üzerine Makaleler, Akçă Yay., Ankara, s.421-442.

3o Bilal Çakıcı (2008), “Za'fi’nin Vardar Yenicesi SSehr-engîzi”, Journal of Turkish Studies / Türklük Bilgisi Araşttrmaları, Şinasi Tekin Hatıra Sayısı III, Volume 32/1, s.169-193.

Bk. Öztürk, 2014: 51-80.

Mustafa Erdoğan (2012), "Bursalı Rahmî ve Yenişehir Şehrengizi”, Erdem Dergisi, sayı 63, s.89-125.

Bahattin Kahraman (1995), "Vahîd Mahtûmî Hayatı, Eserleri, Edebî Kişiliği ve Eserlerinin Tenkidli Metni" Cilt 1-2, Doktora Tezi, Selçuk Üniversitesi, Sosyal Bilimler Enstitüsü, Konya.

34 Lokman Turan (1998), "Yenişehirli Avnî Bey Dîvânı’nın Tahlili (Tenkitli Metin) Encümen-i Şu’arâ ve Batı Tesirinde Gelişen Türk Edebiyatına Geçiş”, Doktora Tezi, Atatürk Üniversitesi Sosyal Bilimler Enstitüsü, s. 581-586. 


\title{
Siroz Şehrengizi
}

Yunanistan'ın kuzeydoğu kesiminde tarihî bir şehir olan Siroz, Osmanlı'nın Rumeli'deki önemli ticaret ve kültür merkezlerinden biridir. Siroz, Yunanistan'da Doğu Makedonya'da Nestos (mesta Karasu) ve Strymon (Struma/Karasu) nehirleri arasındaki ovada Menoikion Dağı'nın (Çayırlı Balkan) eteklerinde denizden 70 metre yükseklikte yer almakta olup Yunanca Serres, Türkçe Siroz ve daha çok Serez olarak adlandırılmıştır (Balta, 2009: 556). Evliyâ Çelebi, Siroz Kalesi’nden bahsettiği yerde Siroz adı hakkında şu bilgileri verir:

\begin{abstract}
“İsim verilme sebebi budur; Yunan dilinde ismi Bikadobor'dur. Gazi Hüdâvendigâr bu kaleyi kuşatıp nice yerden bu kaleyi yıkınca, Müslüman gaziler "Si-rûz, yani bugünkü gün yürüyüş etsinler" deyince yürüyüş edip fetholduğundan ismine Si-rûz derler, yani bugünkü gün kalesi derler, ama halk dilinde bozulmuş hâli kullanıldığından Serez derler.” (2016: 8/68).
\end{abstract}

Şemseddin Sâmî'nin Kâmûsu'l-A'lâm'da verdiği bilgiye göre Siroz, Selanik vilayetini oluşturan üç sancaktan biri olup sancağın merkezidir. Dağlık bir arazi üzerinde yer alan Siroz’un suyu ve havası latiftir; ancak Tahyanos Gölü’nün bataklıkları yazın sıtma hastalığına sebep olur. Bu gölün etrafında güzel bahçeler ve dağ eteklerinde ağaçlık mesirler vardır. Siroz’un toprağı çok verimli ve bereketlidir (1308: IV/2755).

Evliyâ Çelebi, Siroz’un büyük ve süslü bir şehir olduğunu ise şu sözlerle anlatır:

\begin{abstract}
"Evvelâ bu büyük şehrin yan yana üçer ve dörder araba sığar geniş caddeleri iri ve beyaz taşlarla döşeli kaldırımlıdır. Her köşe başında akan çeşmelerin hayat suları taşıp çarşı pazarın sokakların sağında solunda sular akıp güzellik pazarı içinde, bazı caddelerde ve nice meydanlarda çeşit yüksek ağaçlar, salkımsögütler, üzüm asmaları ve uzun serviler ile Acem hıyabanı gibi olmuş, gölgelik ve süslü bir güzel şehirdir ki Rumeli diyarında asla benzeri yoktur. Genellikle kâfiristanın Donkarkız, Danimarka, Lonçat, Amsterdam ve Kaşa adlı şehirleri böyle çeşit çeşit ağaçlarla süslü bakımlı şehirlerdir. Bu Siroz da İslâm şehirleri içinde gayet süslü büyük beldedir.” (2016: 8/73).
\end{abstract}

Klasik Türk edebiyatında Siroz hakkında iki şehrengiz yazılmıştır. Bu iki Siroz şehrengizinden biri Defterdâr-zâde Ahmed Cemâlîye aittir. Mesnevi nazım şekliyle aruzun "Mefầ̂lün/Mefâ îlün/Fe ûlün" kalıbıyla "Şehr-engîz-i Siroz" adıyla yazılan eser, 179 beyitten ibarettir. Şehrengiz, "giriş, münacat, hasb-ı hâl, gece ve gündüz tasviri, Siroz ve güzeller tasviri, hatime” bölümlerinden oluşmaktadır. Eserinin giriş bölümünde bu şehrengizi, şairlik iddiasında bulunmak için yazmadığını, amacının güzelleri övmek ve okuyup dinleyenlerden dua almak olduğunu dile getiren şair, işinin gücünün güzel sevmek olduğunu, aşk ateşiyle Rumeli'de gezmedik yer bırakmadığını, zamanın müstesna güzellerini gördüğü halde bir teselli bulamadığını söyler. Daha sonra gece ve gündüz tasviri yapan şairin yolu, adına Siroz denilen hoş, gönül çeken, güzel ve gönül aydınlatan bir şehre düşer. Bu övgü dolu sözlerle şehir tasviri bölümüne geçen şair, Siroz'un havası, suyu, konumu, yaylaları, akarsuları, binaları, Siroz halkı ve güzelleri hakkında bilgi verir. Siroz’un suyu kevser, havası cennet rüzgârıdır. Her köşesi nimet ve ekinlerle dolu olan Siroz, sanki İstanbul'un bir mahallesidir. Rumeli'nin yüzsuyu olan Siroz'un binalarl, yedi göğe meydan okur; güzelleri cennet hurilerini kıskandırır. İçi peri yüzlülerle dolu olan Siroz, nehir kenarı ve yeşillik bir alana kurulmuştur. Yaz aylarında Siroz halkı, yaylaya çıkma arzusunda olurlar. Bu dünya yaratıldığından beri Siroz’un yaylası gibi süslü, güzel başka bir yer görülmemiştir. Bu yaylalar, soğuk ve coşkun akan pınarlarıyla insana hayat veren birer âb-ı hayâttır. Siroz halkı, işrete düşkün, birbirleriyle yakın ve samimi ilişkileri olan, hoş ve güzel ahlaklı, nazik, nüktedan, iyiliksever, mert ve yüce şanlı kimselerdir. Güzeller tasvirine geçmeden önce Cemâlî, Siroz’un önde gelen bu kişilerinden bazılarının kendisinden gizli bir hazine olan, dünyanın makbul bir sevgilisi olan, inciler saçan bu süslü Siroz hakkında hoş bir şehrengiz yazmasını istediklerini söyler. Kendisinden istenileni yapmaya karar 
veren şair, Siroz'daki bütün güzelleri seyrettiğini, hepsini seçtiğini, şirinlik ve güzellik defterinin dolduğunu, her dükkân ve çarşının peri yüzlü gencecik güzellerle dolu olduğunu fakat kendisinin tasvir edeceği güzellerin dünyanın en saygın ve meşhurları olduğunu belirtir. "Ser-defter-i Hûbân" başlığı ile güzeller tasvirine geçen şair, 24 güzelden ilk üç güzeli beş, sonuncu güzeli yedi, diğerlerini ise üçer beyitle tasvir eder. Eserde, sipahilik, hasiblik, kazzazlık, takyacılık, bakkallık, çıkrıcçılık, debbağlık, kirbasilik, şekercilik ve serraclık o dönemde yapılan meslekler olarak karşımıza çıkar. Güzeller tasvirinden sonra on beyitlik "Hâtimetü'l-Kitâb" başlıklı bölümde şair, güzeller ve eseri için dua ederek şehrengizini sonlandırır. Eser, Lokman Turan tarafindan "Defterdâr-zâde Ahmed Cemâlî'nin Siroz Şehrengîzi” (2011: 53-76) başlı̆̆ıly yayımlanmıştır.

Siroz hakkında yazılan diğer şehrengiz ise adı bilinmeyen bir şaire aittir. Yazılış tarihi belli olmayan eserin tek nüshası İstanbul Üniversitesi Kütüphanesi TY 818 numaralı 74a-78b varakları arasında bulunmaktadır. Bu nüshaya göre eser, 105 beyittir. Şehrengiz, mesnevi nazım şekliyle aruzun "Mefầîü/Mefâ̂ilün/Féûlün" kalıbıyla yazılmıştır. İçerisinde şehir tasviri bulunmayan şehrengiz, "giriş, güzeller tasviri ve hatime” bölümlerinden oluşmaktadır. Şair, şehrengizinde Siroz’un herhangi bir coğrafi, tarihî veya mimari özelliğine yer vermemekle birlikte şehrengizin Siroz hakkında olduğunu eserin giriş bölümündeki Siroz’un gelişip güzelleşmesini, güneş gibi etrafı aydınlatan güzelleriyle meşhur olmasını dile getirdiği beytinde de belirtmiştir:

Husûsâ şehr-i Siroz ola ma‘mûr

Güneş yüzlüleriyle ola meşhûr $\quad$ (b/10)

Şehrengizde bölümleri belirten herhangi bir başlık bulunmamaktadır. Eser, 13 beyitlik giriş bölümüyle başlar. Şehrengize perişan haldeki âşığa seslenerek başlayan şair, ilk dört beyitte âşığın aşk yüzünden çektiklerini ve acizliğini anlatır. Sevgilinin derdiyle aklını kaybeden âşık, aşk şarabıyla kendinden geçmiş ve bu dünyada kendini unutmuştur:

Elâ ey ‘âşık-ı şûrîde-meşreb

Sirişti ‘aşk u sevdâdan mürekkeb

[...]

Özinden bî-haber 'aklı perîşân

Şarâb-ı 'aşkla ser-mest ü hayrân $\quad(b / 1,3)$

Daha sonra şair, sarhoşlar içinde dertten rezil olanı, muhabbet ehlinin değersiz kölesini, gençlere düşkün olanları, ihtiyarların yüzüne bakmayanları, ayıplanmaları duymayan, bir an bile elinden kadehi bırakmayanları vereceği öğüdü can kulağı ile dinlemeye çağırır ve onlara bahar geçmiş, sonbahar gelmiş olsa da en azından sonbaharın kıymetini bilmelerini öğütler:

Harâbâtîlerüñ rüsvâ-yı gâmı

Muhabbet ehlinüñ kem-ter gulâmı

Ölümlüsi olan her nev-cüvânuñ

Yüzine bakmayan zâl-i zamânuñ

Kulaha koymayan ta'n-ı 'avâmı

Elinden komayan bir lahza câmı 
Gel imdi pendümi cânile gûş it

Dem-i köhne bahâr irişdi cûş it

Bahâruñ n'ola geçdiyse zamânı

Geçürme bâri gel devr-i hazânı

(b/5-9)

Sözlerine Siroz’un bayındır olmasını ve güzelleriyle meşhur olmasını istediğini söyleyerek devam eden şair, âşık vasfında kendisine seslenerek güzellerden her birinin övülmeye layık olduğunu, onları vasfetmesini, sözlerini kısa tutarak itibar görmesini, güzellerin vasıflarını anlatmaya ve melekler adını yazmaya başlamasını söyler:

Husûsâ şehr-i Siroz ola ma'mûr

Güneş yüzlüleriyle ola meşhūr

Niçün vasf itmeyesin anı 'âşık

Olupdur medhe her vechile lâyı

Velîkîn muhtasar eyle kelâmuñ

Anuñla mu‘teber eyle kelâmuñ

Güzeller vasfinı takrîre başla

Melekler adını tahrîre başla $\quad$ (b/10-13)

$\mathrm{Bu}$ beyitlerle şair, şehrengizi yazma sebebini dile getirir ve güzeller tasvirine geçiş yapar. Eserde, güzellerin övgüsü 14. beyitten itibaren başlar ve 97 . beyte kadar sürer. Bu bölümde 28 güzelden her biri üçer beyitle tanıtılmıştır. Şair, şehrengiz geleneğine uyarak şehrin 28 güzelini biri dışında ya meslek ya baba adı/lakabı/mesleği ya da sadece isim veya lakabını vererek tavsif etmiştir. Eserde sadece üç güzelin tasvirinden önce başlık kullanılmıştır: Yeniçeri-zâde Mehemmed Kâtib (b.86-88), Akçelü Mustafa Çelebi-zâde (b.89-91), Berber Ahmed (b.92-94). Şehrengizde 8 güzel mesleğiyle, 10 güzel baba adı/lakabı/mesleğiyle, 8 güzel sadece ismiyle, 1 güzel lakabıyla tanıtılmış; 1 güzel hakkında ise herhangi bir bilgi verilmemiştir:

Mesleği verilenler: Sipâhî, Kazzâz Hüseyin, Sipâhî Mustafâ, Başmakcı İsâ, Başmakcı Ahmed, Yeniçeri-zâde Kâtib Mehemmed, Berber Ahmed, Berber

Baba adı/lakabı/mesleği verilenler: Rüstem oğlu, Eşekci-zâde, Mûtâf-zâde, Derzi-zâde Hasan Bâlî, Güreldi-zâde, Tarak Voyvoda oğlu, Ebrî Bâlî oğlu Mehemmed, Ferhâd-zâde, Acem-zâde, Akçelüzâde Mustafâ.

İsmi verilenler: Halîl, Yahyâ, Dâvud, Dervîş Bâlî, Memi (Kazzâz Hüseyin’in kardeşi), Alî, Celîl, Mehemmed Şâh.

Lakabı verilenler: Ak Gül Mehemmed Şâh. 
Şehrengizinde güzeller tasvirinden sonra 8 beyitlik hatime bölümüne geçen şair, güzellerin övgüsünü bitirdiğini, eksikleri olabileceğini ama ilim ehlinin hatalarını düzeltmesini ümit ettiğini, yeteneği olmadığını fakat gücünün yettiğince eserini yazdığını söyleyerek eserindeki eksiklerin hoş görülmesini ister. Şarap ve güzel konusunda iradesine hâkim olamayan, bütün varını güzeller yoluna feda etmeye razı olan, her türlü arzu ve isteğinden vazgeçmesine rağmen güzellerden vazgeçemeyen, makam ve itibarda gözü olmayan şair, Allah’tan güzelsiz kalmamayı diler ve tek arzusunun güzellerden birine kavuşmak olduğunu söyleyerek şehrengizini tamamlar:

\author{
Kusûrını ide ıslâh yir yir \\ Yahûd ol semtine olmaya nâzır \\ $[\ldots]$ \\ Mey ü mahbûba yokdur ihtiyârum \\ Fedâdur yollarına cümle varum \\ $[\ldots]$ \\ Gerekmez baña hergiz ‘izz ü câhı \\ Beni bunlarsuz itme yâ İlâhî
}

Beni yâ Rab birine eyle kâdir

Budur senden murâdum evvel âhir

Şehrengizde güzeller, biri dışında adı, lakabı, mesleği veya baba adı/lakabı/mesleğinden herhangi biri genellikle ilk beyitte verilerek diğer beyitlerde de bunlar etrafında oluşan kelimelerden yararlanılarak tasvir edilmiştir. Eser, bu yönüyle şehrengiz türünün yapısına uygunluk göstermektedir. Şehrengizinde güzelleri "kamer-veş, perî-zâd, âfet, ş̂ve-ger, sanem" gibi sıfatlarla niteleyen şair, klasik Türk şiirindeki ideal güzel anlayışıyla güzellerin fiziksel özelliklerini de "gonce-dehân, perî-rû, sîmîn-beden, semenhad, serv ü sîm endâm" gibi benzetmelerle anlatmıştır.

Şehrengizde Hüseyin adlı güzelin mesleği kazzazlıktır. Kazzaz, ham ipeği işleyip iplik ve ibrişim haline getiren, ipek satan, ipekçi anlamına gelmektedir (Devellioğlu, 2013: 575). İpekçi Hüseyin’in tasvirinde de "bükmek, döğmek, iliğine geçmek, yara (düğme deliği, ilik), ebrişim" gibi ipekçilikle ilgili kelimelere yer verilmiştir. Eskiden düğmelerin önemli bir kısmı iplikle örülerek yapıldı̆̆ı için ipekçiler, ibrişimden örülmüş düğmeler yapıp satıyorlardı (Şen, 2002: 68). Geçmişte şimdiki sadef ve madenî düğmeler yerine ipekle işlenmiş olanları kullanılmaktaydı. Günümüzde de bazen elbiselere kendi kumaşından düğme ördürülmektedir (Onay, 2013: 230). Şair de güzelin tasvirinde ipekle düğme yapımını, ibrişim, iplik ve düğmenin geçtiği iliği vurgulamıştır:

Hüseyn adı birisi dahı kâzzâz

Belüm bükdi benüm yâr-ı tannâz

İşi uşşâkı dögme sögme anuñ

İligine geçübdür ben gedânuñ

Esîr-i kâküliyüm dime zinhâr

Getürmez yaraya ebrişim ol yâr $\quad(b / 50-52)$ 
Şair, sevgilinin aşkından belinin bükülmesi ile ipeğin bükülerek işlenmesine, güzelin yaptığı eziyetlerin etkisini ifade ettiği "iliğine geçmek" deyimiyle ipekten düğme yapımına ve düğmenin geçtiği iliğe, güzelin tel tel olan kâkülüyle de ibrişime gönderme yapmıştır.

Güzellerden Yeniçeri oğlu Kâtip Mehemmed'in tasvirinde de "hat, hâme, mürekkeb, kitâbet, yazmak, kitâb etmek” gibi mesleğine gönderme yapan kavram ve ifadelere yer verilmiştir. Yasemin yüzlü Yeniçeri oğlu Mehemmed güzel yazı yazmayı istemektedir. Bu şeker dudaklı, güzel yazı yazarken kullanır mı bilinmez ama şairin kirpiği ona kalem, kanı da mürekkeptir. Şair, kâtipliği bildiğini söylediği gönlünden, güzelin sahip olduğu özellikleri yazıp kitaplaştırmasını ister:

\title{
Biri Yeñiçeri oglı Mehemmed
}

Olupdur tâlib-i hat ol semen-had

\section{Müjem hâme aña kanım mürekkeb}

Yazar mı kanı andan ol şeker-leb

Bilürsüñ sen dahı ey dil kitâbet

Anuñ vasfinı yazup bir kitâb et $\quad$ (b/86-88)

Şair kirpiklerini şekil olarak kaleme, kanını da kırmızı rengi bakımından mürekkebe benzetmiştir. Son beyitte güzelin mesleğiyle ilgi kurularak "kitâbet" ve "kitâb et" kelimeleriyle cinas yapılmıştır.

Şehrengizde baba mesleğiyle tanıtılan güzellerden biri olan Mûtâf-zâde'nin babası keçecilik yapmaktadır. Tiftik keçisi, koyun, tavşan, deve veya lamanın yün veya kılının ısıtılıp dövülmesiyle yapılan kaba ve kalın bir kumaş çeşidi olan keçeden külah, çizme, çorap, terlik, yer döşemesi, kapı perdesi, çadır gibi birçok şey yapılmaktadır (Çeliker, 2011: 1; Koçu, 2015: 156). Keçeci de keçe yapan ve satan kimsedir. Keçeci oğlu, “mû, çul, kara çul” gibi babasının mesleğine yapılan göndermelerle tanıtılır. Peri yüzlü keçeci oğlunun belinin düşüncesi şairin vücudunu kıl yapmış; kıl gibi inceltmiştir. Bu yüzden şairin, güzelin saçı sevdasıyla kara çullar giymesine şaşılmamalıdır. Şairin âşı gönlü başka bir güzeli istemez; çünkü boş torba ile at tutulmaz:

\author{
Biri Mûtâf-zâde bir perî-rû \\ Miyânı fikri kıldı cismümi mû \\ Giyersem n'ola ben âvâre çullar \\ Saçı sevdâsıyla kara çullar
}

Dil-i dîvâne andan özge bulmaz

Velî boş torba ile at tutulmaz $\quad(\mathrm{b} / 38-40)$

Divan şiirinde sevgilinin beli incelik bakımından kıla benzetilir. Şair de güzelin belinin inceliği ile kıl arasındaki ilişkiden hareketle güzelin ince belinin düşüncesinin bile âşı̆̆ı kıl gibi inceltip zayıflattığını dile getirmiştir. "Âvâre" kelimesi ise "âşık, düşkün, kendinden geçmiş" anlamına gelmekle birlikte tekstilde "astar, gösterişsiz elbise" gibi anlamlara da gelmektedir (Şentürk, 2016: 418). Şair de güzelin anlatımında "âvâre" kelimesini her iki anlama gelecek şekilde tevriyeli kullanmıştır. Çul "kıldan yapılan kalın dokuma" anlamına gelmekle birlikte "giyim, giysi" anlamına da gelir (TDK, 2011: 570). Şair de 
güzelin baba mesleğiyle ilişkili olarak aşk yüzünden perişan bir hale geldiğini, eski püskü elbiseler giydiğini "âvâre çullar giyersem" şeklinde ifade etmiştir. Aynı beyitte "saç, sevda ve kara çul" kelimeleri arasında siyah renk bakımından ilgi kuran şair, güzelin saçlarının aşkı/siyahıyla kara çullar giymesinde şaşılacak bir durum olmadığını söyler. Zaten çul, divanelikle özdeşleşmiş̧ir. Atların yem yediği torbanın keçeden yapılmasından hareketle son beyitte şair "çıkarı olmadan bir kimsenin bir yere bağlanamayacağı, özveride bulunmadan istenilen şeyin elde edilemeyeceği” anlamına gelen "boş torba ile at tutulmaz" atasözünü kullanmıştır (Aksoy, 2013: 205). Bu atasözünün hikâyesi ise eskiden başıboş atları yakalamak için içi arpa dolu torbalar kullanılmasına dayanmaktadır. Bu torbalar atlara yaklaştırılarak atlar kafalarını torbanın içine soktukları an yakalanırmış.

Kelime olarak Allah yolunda alçakgönüllüğü ve fakirliği kabul eden kimse anlamına gelen derviş, bir tarikata bağlı olan kişi; abdâldır (Devellioğlu, 2013: 200, 224). Şehrengizdeki Derviş adlı güzel de "esrâr, hayrân, abdâl, perîşân-hâl, tekye-i ‘âşk" gibi dervişliğe çağrışım yapan kelime ve tabirlerle tasvir edilmiştir. Sır kelimesinin çoğulu olan esrar, abdal ve kalenderî denilen batınî dervişler arasında yaygın olarak kullanılan bir maddedir. Esrar içilen yerlere de tekke denilmektedir. Hayran kelimesi ise hayret makamındaki hale işaret eder (Şahin, 2011: 356). Dervişlerin özelliklerinden biri de saçlarını ya kazıtmaları ya da uzatmaları, örmeleri veya topuz yapmalarıdır (Göre, 2015: 47):

\section{Biri Dervîş Bâlî âfet-i cân}

Lebi esrarına 'uşşâk hayrân

Ezelden 'aşkınuñ abdâlıdur dil

Saçı gibi perîşân-hâlidür dil

Kabûl itse eger benden dahı cân

Olurdum tekye-i 'aşkında kurbân (b/32-34)

Sade bir dille kaleme alınan şehrengizde "boş torba ile at tutulmaz (b. 40)" atasözü ve "kendini unutmak (b.4), yüzüne bakmamak (b. 6), kulağa koymamak (b.7), kurban olmak (b. 16, 34, 67), derdine derman olmak (b. 21), yoluna baş koymak (b. 35), elden gitmek (b. 45), belini bükmek (b. 50), iliğine geçmek (b. 51), bir içim su (b. 53), can yakmak (b.56), kiyamete kadar (b. 60), teselli etmek (b. 66), helak etmek (b. 71), ele girmek (b. 72), başı göğe ermek (b. 72), vücuda gelmek (b.81), yüz döndürmek (b. 94)” gibi deyimlere yer verilmiştir.

Şehrengiz içinde özellikle güzeller tasviri bölümünde cinaslı kullanımlar yer almaktadır:

Görüp âyîne-i kalbüñ cilâsın

Göründi bana ol yâr-ı cilâsın ～(b/57)

Bilürsüñ sen dahı ey dil kitâbet

Anuñ vasfinı yazub bir kitâb et

Keserse tîgle başuñ o server

Yüzüñ döndürme andan cân u ser ver （b/94） 
Şehrengizde dönemin mutfak kültürüne dair de palude tatlısı geçmektedir. Palude, Türkçe "pelte", Arapça "fâlûzec", Farsça "süzülmüş, inceltilmiş" anlamına gelen "pâlûda" veya "pâlüze"den gelmektedir. Farklı tarifleri olmakla birlikte günümüz peltesine en çok benzeyen palüze tarifine göre balla nişasta kaynatılır, koyulaşınca buna badem dilimleri ilave edilir ve üzerine şekerli gülsuyu dökülüp yenilir. Ayrıca palüzenin bir çeşit badem ezmesi olduğu ve salep gibi bir içecek olarak tüketildiği de kaynaklarda geçmektedir (Işın, 2009: 204, 208):

Dir idüm cismine pâlûde beñzer

Velîkin korkarın baña düşe ter

$(\mathrm{b} / 49)$

\section{Sonuç}

Klasik Türk edebiyatında şehrengiz, XVI. yüzyılda ortaya çlkmış ve çok rağbet görmüş, XVIII. yüzyıldan sonra rağbetten düşmüştür. Şairler, doğup büyüdükleri memleketleri, bir süre yaşadıkları veya gördükleri şehirler hakkında şehrengiz kaleme almışlardır. "Bursa, Edirne, İstanbul” gibi Osmanlı Devleti'ne başkentlik yapmış şehirlere şehrengiz yazıldığı gibi sosyo-kültürel ve ekonomik açıdan önemli bir yere sahip olan "Belgrad, Gümülcine, İştip, Mostar, Moton, Rodos, Siroz, Üsküp, Yenice, Yenişehir" gibi Rumeli şehirleri adına da şehrengiz yazılmıştır. Mevcut bilgilere göre bu Rumeli şehirlerinden Siroz hakkında iki şehrengiz kaleme alınmıştır.

Bu çalışmaya konu olan şairi ve yazıldığı tarih bilinmeyen Siroz Şehrengizi, Siroz hakkında yazılan iki şehrengizden biridir. 105 beyitlik Siroz Şehrengizi, şehir tasvirinin bulunmaması dışında hem bölüm tertibi hem de şehrin güzellerini övmesi bakımından türün özelliklerini yansıtmaktadır. Tek nüshası tespit edilen eserde Siroz'un tarihi, coğrafyası veya mimarisi hakkında herhangi bir bilgi bulunmamaktadır. Ancak şehrengizde daha çok esnaf grubu olmak üzere dönemin mesleklerinden "kazzazlık, başmakçılık, berberlik, keçecilik (mûtâf), terzilik, kâtiplik, sipahilik, voyvodalık, eşekçilik" yer almaktadır. Adı bilinmeyen şair tarafından sade bir dille yazılan Siroz Şehrengizi, yazıldığı dönemin meslekleri, halkın isim ve lakap kullanımı hakkında bilgi vermesi bakımından sosyo-kültürel bir değere sahiptir. 
74-a

\section{Mefāîiün/Mefāīilün/Feūülün}

1 Elā ey 'āşıḳ-1 şūrīide meşreb

Sirişti 'aşk u sevdādan mürekkeb

2 Ġam-1 cānānla abdāl olmış

Benüm gibi perīşān-ḥāl olmış

3 Özinden bī-ḩaber 'aḳlı perīşān

Şarâb-1 aşḳla ser-mest ü ḥayrān

4 Unutmış kendüzini bu cihānda

Ne evde göñli gibi ne yabānda

5 Ḥarābātīlerüñ rüsvā-yı gāāmı

Muhabbet ehlinüñ kem-ter ġulāmı

6 Ölümlüsi olan her nev-cüvānuñ

Yüzine bakmayan zāl-i zāmānuñ

7 Kulaha ḳoymayan țain-1 'avāmı

Elinden ḳomayan bir lạ̣za cāmı

8 Gel imdi pendümi cānile gūş it

Dem-i köhne bahār irişdi cūş it

9 Bahāruñ n'ola geçdiyse zamānı

Geçürme bāri gel devr-i ḩazānı

10 Husụūṣā şehr-i Siroz ola ma'mūr

Güneş yüzlüleriyle ola meşhūr

11 Niçün vașf itmeyesin anı 'āşık

Olupdur medhe her vechile lāyık

12 Velīkin muhtașar eyle kelāmuñ

Anuñla mu'teber eyle kelāmuñ

\section{Metin}

13 Güzeller vașfını taḳirire başla

Melekler adını tahrīre başla

74-b

14 Hualīl adı ser-āmed bir ḳamer-veş

Ruḩ-1 rengīni urdı cāna āteş

15 Dil-i virānemi eyler ser-ābād

İder bir Ka'be bünyād ol peri-zād

16 Olurdum cānla kurbānı anuñ

Olaydum bir gice mihmānı anuñ

17 Birisi Rüstemüñ og̉ lı ol āfet

Dil ü cān kişverini itdi gāaret

18 Gözi șāḥib-ḳırān mānend-i Ḥamza

Ya Sām u Kahramāndur șan o gamze

19 Eşigi variken ol nev-cüvānuñ

Yüzine baḳanı zāl-i cihānuñ

20 Mesịhāā-dem biri bir yār-1 cāndur

Dimem adın anuñ yannī filandur

21 Helākīdür o dil-dāruñ dil ü cān

Lebi ben hastanuñ derdine derman

22 O gonçe cāme-i sebz ile güyā

Gelüpdür bir yire Hुıżr u Mesīhāa

23 Mehemmed Şāhdur sulțān-1 hū̄āan

Anuñ ḥükmündedür hū̄oān-1 devran

24 Laḳap Aḳ Güldür ol gononçe dehāne

Laḳap gögden inipdür ol cüvāne

$75-\mathrm{a}$

25 Ser-āmed şimdi oldur şehr içinde

Naziiri yoḳdur anuñ dehr içinde 
440 / RumeliDE Journal of Language and Literature Studies 2019.16 (September)

A shehrengiz of Siroz by an unknown poet / D. Karaca (p. 428-444)

26 Biri bir şīie-gerdür adı Yahyā

Leb-i cān-bahşş mürde eyler iḥyā

27 İder bir laḥz̧ada biñ dürlü şīe

Șanasın pür durur bir şişe jīive

28 Kitāb-1 'işveyi itmiş tamām ol

Olupdur nāz u şīiveyle be-nām ol

29 Birisi dāḩı Dāvud-1 ḩoş-elhāan

Anuñ fermān-berīdür insile cān

30 Süleymān dir isem aña yiri var

Hevā-dārı anuñ niçe perī var

31 Olursam n'ola anuñ sīne-çāk1

Hilāl ebrūsunuñ oldum helākı

32 Biri Dervīş Bālī āfet-i cān

Lebi esrārına uşşāk hayrān

33 Ezelden 'aşkıınuñ abdālıdur dil

Șaçı gibi perīşān-ḥālidür dil

34 Kabūl itse eger benden dahı cān

Olurdum tekye-i aş̧̣ıında ḳurbān

35 Eşekci-zādedür birisi anuñ

Ḳoduḳ başı yolına ol cüvānuñ

$75-b$

36 Kaçan görsem raḳib-i ebterile

Șanuram anı ' îsādur ḩarile

37 Olaldan yār ag̉yār ol hümāya

Dönüpdür segbana çıkmış sıpaya

38 Biri Mutāf-zāde bir perī-rū

Miyānı fikri ḳıldı cismimi mū
39 Giyersem n'ola ben āvāre çullar

Ṣaçı sevdāsıyla ḳara çullar

40 Dil-i dīvāne andan özge bulmaz

Veli boş torba ile at țutulmaz

41 Hasan Bālī birisi Derzi-zāde

Beni āvāre ḳılmışdur ziyāde

42 Olur yine diyü bì-çāre sīne

Șaḳın atılma anuñ pāresine

43 Görüp miḳrāżını dil ıżțırārı

Oḳur lā seyfe illā żü'l-fikāàr

44 Sipāhīdür birisi bir dilāver

Serīr-i hüsne oldur şimdi server

45 Süvār olsa ḳaçan ol şeh-süvārum

Gider elden inān-1 iḩtiyārum

46 Dil ü cānum o şāhuñ bendesidür

Kamū halḳ-1 cihān efgendesidür

47 Güreldi-zāde bir sīmīn bedendür Șanasın Yūsuf-1 gül-pīrehendür

$76-\mathrm{a}$

48 Der-āgūuş eyleyen ol yār-1 cānı

Bulur ey dil hayāt-1 cāvidānı

49 Dir idüm cismine pālūde beñzer

Velikin ḳorḳarın baña düşe ter

50 Ḥ̈̈seyn adı birisi dāḩı ḳazzāz

Belüm bükdi benüm yār-1 țannāz

51 İşi usşāḳ̂ dögme sögme anuñ

İligine geçübdür ben gedānuñ 
52 Esīr-i kāküliyüm dime zinhār

Getürmez yaraya ebrişim ol yār

53 Karındaşı Memi ḩod yār-1 nāzük

Bir içim sudur ol dil-dār-1 nāzük

54 Henüz nev-reste bir şūh̆-1 cihāndur

Șanasın ġonçe-i bāg -1 cināndur

55 Güzeller hayli ider aña meyli

O țfluñ cümlesi olmış țufeyli

56 Tarak Voyvoda og̉l ol dilāver

Yaḳubdur cān u dil mülkin ser-ā-ser

57 Görüb āyīne-i ḳalbüñ cilāsın

Göründi baña ol yār-1 cılāsın

58 İşi dāim anuñ merdānelikdür

Esīi olmamaḳ dīvānelikdür

76-b

59 Sipāhī Muștafānuñ ḥastasıyum

Esīriyüm şikeste-bestesiyüm

60 Eger ben hastaya itmezse tīmār

Kalurum tā ḳıāmet şöyle bīmār

61 Dilā sen șaḳlıya gör tīirin anuñ

Ben aldum boynuma şemşīin anuñ

62 'Alī adı birisi pür-şecā'at

Velikkin būsede itmez sehāvet

63 Anuñla nūş ideydüm 'aşḳ cāmın

Bulurdum laḥmike laḥmi maḳāmın

64 İlāhī huidmetine eyle Ḳanber

Bi-hakḳıı izzet-i nūr-1 sīm-ber
65 Olıgör bendesi ey dil Celīlüñ

Celāle irmege oldur delīiüñ

66 İdüpdür tā ezel baña tecellì

Beni anuñla ḳılmışdur teselli

67 Eger kim milleti iseñ ḩalīiüñ

Kulı ḳurbānı olıgör Celīiüñ

68 Güzellerden biri dāḩı ser-āmed

Ki Ebrī Bāli og̉lıdur Meḥemmed

69 İdeydi ol șanem ger 'arż-1 dīdār

Muhammed ümmeti olurdı küffār

70 Anuñ kūyı șafā ehline besdür

Hevā-y1 rāh-1 hac zāid-hevesdür

$77-\mathrm{a}$

71 Helāk itdi beni Başmakcı İsā

Dirildür mürdeyi gerçi Mesīhā

72 Ele girse ayaġındağı başmak

İrerdi gün gibi başum göge çak

73 Perī șūretlü bir zībā șanemdür

Gül-āb-1 Meryem içre niçe demdür

74 Anuñ Başmaḳcı Aḥmeddür birisi

Begāāet çoḳdur anuñ müşterisi

75 Biz anuñ tỉgine māillerüz hep

Güle baḳduginna ḳāillerüz hep

76 Baña ol ġamzeler çog işler işler

Gelen başına başmaḳcı dimişler

77 Meḥemmed Şāhdur cānı cihānuñ

Beni öldürdi çeşm-i mesti anuñ 
442 / RumeliDE Journal of Language and Literature Studies 2019.16 (September)

A shehrengiz of Siroz by an unknown poet / D. Karaca (p. 428-444)

78 Virür gerçi ki būse dest-ber-dest

Getürür ayaġı olsa ḳaçan mest

91 Olaydı bende ger dirhem ya dīnār

Olurdum vaṣlına anuñ ḩarīār

79 Temāşā it diyü başında yelken

Șalar 'āşı̣lara el her țarafdan

Berber Ahmed

92 Birisi berber Aḥmed pür-lețāet

Açupdur hüsni dükkān-1 melāḥat

80 Biri şīīin dehen Ferhād-zāde

Anuñ mecnūnı oldum ben fütāde

93 Aña kirpiklerüm çün şānelerdür

İki çeşmüm dahı āyinelerdür

81 Vücūda gelmemişdi dāḩı Ferhād

İderdüm bī-sütūn-1 gamda feryād

82 Yüzi kim hü̈srev-i hā̄ver olupdur

Cebīnine ḳamer çāker olupdur

$77-b$

83 'Acem-zāde biri bir yār-1 meh-veş

Dil ü cān kişverine urdı āteş

84 Anuñ hem-demleri olaldan evbāş

Çıḳupdur ḳara bag̉rımda ḳızıl baş

85 Dilerseñ āşinā olmaḳ aña sen

Yüri var gel 'Arabdan yā 'Acemden

\section{Yeñiçeri-zāde Meḥemmed Kāātib}

86 Biri Yeñiçeri og̉ı Meḥemmed

Olupdur țālib-i haț ol semen-ḩad

87 Müjem ḩāme aña ḳanım mürekkeb

Yazar mı ḳanı andan ol şeker-leb

88 Bilürsüñ sen dahı ey dil kitābet

Anuñ vașfını yazub bir kitāb et

\section{Akçelü Mușțafā Çelebī-zāde}

89 Birisi Akçelü-zāde o dil-ber

Hemān bir serv ü sīm endāma beñzer

90 Eyitdüm ben faḳire eyle ị̣sān

Didi kim akçedür derdüñe dermān

100 Kusụūrını ide 1ṣlāḥ yir yir

Yahūd ol semtine olmaya nāẓır

94 Keserse tīg̀le başuñ o server

Yüzüñ döndürme andan cān u ser ver

78-a

95 Dilā șayd ide gör bir yir maḥali

Var ise berber olmak ihtimāli

96 Legenlerdür aña mihr ü meh altun

Velī baş kesmek olmış aña ḳānūn

97 Göñül 'aşḳıında ser-gerdān olupdur

Aña bu sīnem āteş-dān olupdur

98 Tamām oldı egerçi medḥ-i huūbān

Velī olmışdurur ber-vech-i noḳșān

99 Ümīd oldur ki erbāb-1 ma ārif

Bunuñ nokșānına oldukda vâkıf

101 Egerçi yoḳdurur bende liyāḳat

Velīkin söyledüm yetdükçe țāḳat

102 Mey ü maḥbūba yoḳdur ihtiyārum

Fedādur yollarına cümle varum

103 Göñül urdı ḳamu mațlūb terkin

Velīkin urmadı maḥbūb terkin 
105 Beni yā Rabb birine eyle ḳādir

Budur senden murādum evvel āḩir

\section{Kaynakça}

Adak, A. (2006). “Za’fî-i Gülşenî Hayatı, Eserleri, Edebî Şahsiyeti ve Dîvânının İncelenmesi”, Doktora Tezi, Ankara Üniversitesi, Sosyal Bilimler Enstitüsü, Ankara.

Akkuş, M. (1987). "Türk Edebiyatında Şehr-engîzler ve Bursa Şehr-engîzleri”, Yüksek Lisans Tezi, Atatürk Üniversitesi, Sosyal Bilimler Enstitüsü, Türk Dili ve Edebiyatı Ana Bilim Dalı, Erzurum.

Aksoy, Ö. A. (2013). Atasözleri ve Deyimler Sözlüğü, Atasözleri Sözlüğü 1, İstanbul: İnkılâp Kitabevi.

Âşık Çelebi (2010). Meşa ‘irü’ş-Şu'arâ, Haz. Filiz Kılıç, 3 Cilt, İstanbul: İstanbul Araştırmaları Enstitüsü.

Aydemir, Y. (2001). "Sani’nin Rodos Şehrengizi”, Türk Kültürü, S. 455, s.167-174.

Balta, E. (2009). "Serez", Türkiye Diyanet Vakfı İslam Ansiklopedisi, C.36, Ankara: Türkiye Diyanet Vakfı Yayınları, s. 556-558.

Çakıcı, B. (2008), "Za'fi’nin Vardar Yenicesi Şehr-engîzi”, Journal of Turkish Studies / Türklük Bilgisi Araştırmaları, Şinasi Tekin Hatıra Sayısı III, Volume 32/1, s.169-193.

Çakıcı, B. (2010), "The Shahrangiz of Shtip by Za'fi", İnternational Journal of Central Asian Studies, Volume 14, Korea, s. 95-107.

Çavuşoğlu, M. (1969). “Taşlıcalı Dukakin-zade Yahya Bey’in İstanbul Şehrengizi”, Türk Dili ve Edebiyatı Dergisi, Ağustos 1969, C.XVII, s.73-108.

Çavuşoğlu, M. (1973-1974). "Hayreti’nin Belgrad Şehrengizi”, Güney-Doğu Avrupa Araştırmaları Dergisi, C.II-III, s.325-356.

Çavuşoğlu, M. (1975-1976). “Hayreti’nin Yenice Şehrengizi”, Güney-Doğu Avrupa Araştırmaları Dergisi, C.IV-V, s. 81-100.

Çavuşoğlu, M. (1977). "Şehrengiz-i Edirne”, Yahya Bey: Divan, İstanbul Üniversitesi Edebiyat Fakültesi Yayınları, İstanbul, s. 227-243.

Çeliker, D. (2011). "Geçmişten Günümüze Türklerde Keçecilik ve Keçe Yapımında Yeni Teknikler”, Süleyman Demirel Üniversitesi Güzel Sanatlar Fakültesi Hakemli Dergisi ART-E Kasım, s.1-22.

Çeltik, H. (2009). "Rumeli Şairlerinin Klâsik Türk Şiirine Katkıları", Turkish Studies Volume 4/8 Fall 2009, s. 804-824.

Devellioğlu, F. (2013). Osmanlıca-Türkçe Ansiklopedik Lûgat, Ankara: Aydın Kitabevi.

Erdoğan, M. (2012). "Bursalı Rahmî ve Yenişehir Şehrengizi”, Erdem Dergisi, sayı 63, s.89-125.

Evliyâ Çelebi (2016). Günümüz Türkçesiyle Evliyâ Çelebi Seyahatnâmesi, Haz. Seyit Ali Kahraman, C.2, İstanbul: Yapı Kredi Yayınları.

Göre, Z. (2015). "Za'f̂i-i Gülşenı̂’nin Moton Şehrengizi”, Osmanlı Mirası Araştırmaları Dergisi (OMAD), C.2, (4), Kasım, s. 41-57.

Işın, P. M. (2009). Gülbeşeker: Türk Tatlıları Tarihi, İstanbul: Yapı Kredi Yayınları.

İnalcık, H. (2008). “Rumeli”, Türkiye Diyanet Vakfı İslam Ansiklopedisi, C. 35, Ankara: Türkiye Diyanet Vakfı Yayınları, s. 232-235.

İsen, M. (1988). “Usuli’nin Yenice Şehrengizi”, Türk Kültürü Araştırmaları (Mehmed Kaplan İçin), s.131148.

İsen, M. (1997). "Usuli’nin Yenice Şehrengizi”, Ötelerden Bir Ses Divan Edebiyatı ve Balkanlarda Türk Edebiyatı Üzerine Makaleler, Akçă̆ Yayınları, Ankara, s.421-442.

İsen, M., H. B. Burmaoğlu (2011). Bursa Şehrengizi (Lâmîî Çelebi), Bursa Büyükşehir Belediyesi. 
Kahraman, B. (1995). "Vahîd Mahtûmî Hayatı, Eserleri, Edebî Kişiliği ve Eserlerinin Tenkidli Metni” Cilt 1-2, Doktora Tezi, Selçuk Üniversitesi, Sosyal Bilimler Enstitüsü, Konya.

Karaca, D. (2018a). "Zâtî’nin Edirne Şehrengizi”, Uluslararası Sosyal Araştırmalar Dergisi/The Journal of International Social Research, Şubat, C. 11, S. 55, s. 114-136.

Karaca, D. (2018b). “Türk Edebiyatında Şehr-engîzler "Şehirler ve Güzeller"”, Doktora Tezi, İnönü Üniversitesi Sosyal Bilimler Enstitüsü, Türk Dili ve Edebiyatı Ana Bilim Dalı, Malatya.

Karacasu B. (2006). “'Bize Çengîleri Kıl Rûşen ü Pâk' ya da 'Hayra Hezlin Dahi Bir Rehberi Var”, Osmanlı Araştırmaları Dergisi (Prof. Dr. Mehmed Çavuşoğlu'na Armağan III), S.27, s.133-160.

Kaya, H. (2015). "Kâtib Davud'un İstanbul ve Vize Şehrengizi”, Turkish Studies-International Periodical For The Languages, Literature and History of Turkish or Turkic,, Volume 10/12, Summer, s.631686.

Keklik, M. (2014). "Üsküplü İshâk Çelebi Divan (Metin-Çeviri-Açılamalar-Dizin)”, Doktora Tezi, Kırgizistan-Türkiye Manas Üniversitesi, Sosyal Bilimler Enstitüsü, Türkoloji Ana Bilim Dalı, Bişkek.

Kesik B. (2010). "Yeni Bir Nüshadan Hareketle Hacı Derviş’in Mostar Şehrengizi”, Turkish Studies, Volume 5/3, Summer, s. 368-399.

Koçu, R. E. (2015). Türk Giyim Kuşam ve Süslenme Sözlüğü, İstanbul: Doğan Egmont Yayınları.

Kuru, S. S. (2005), “Biçimin Kıskacında Bir 'Tarih-i Nev-icad’: Enderunlu Fazıl Bey ve Defter-i Aşk Adlı Mesnevisi”, A. Festschift For Şinasi Tekin, Haz. Günay Kut- Fatma Büyükkarcı Yılmaz, İstanbul: Simurg Yayınları, s. 476-506.

Onay, A. T. (2013). Açılamalı Divan Şiiri Sözlüğü Eski Türk Edebiyatında Mazmunlar ve İzahı, Haz. Cemal Kurnaz, Ankara: Berikan Yayınları.

Öztürk, N. (2002). "Zenânnâme Enderûnlu Fâzll”, Yüksek Lisans Tezi, İstanbul Üniversitesi, Sosyal Bilimler Enstitüsü, Türk Dili ve Edebiyatı Ana Bilim Dalı, İstanbul.

Sungur, N. (2006). Tâcî-zâde Cafer Çelebi, Heves-nâme (İnceleme-Tenkitli Metin), TDK, Ankara.

Şahin, E. (2011). “Bâkî Divanı’na Göre 16. Yüzyll Osmanlı Toplum Hayatı”, Doktora Tezi, İstanbul Üniversitesi Sosyal Bilimler Enstitüsü. Türk Dili ve Edebiyatı Ana Bilim Dalı, İstanbul.

Şairi Bilinmeyen Şehr-engîz-i Siroz. İstanbul Üniversitesi Kütüphanesi, TY 818 (v.74a-78b).

Şemseddin Sâmî (1308). Kâmûsu'l-A'lâm, C. 3, İstanbul: Mihran Matbaası.

Şen, F. M. (2002). “Tâcîzâde Cafer Çelebi Dîvânı’nda XV. ve XVI. Yüzyll Toplum Hayatı”, Doktora Tezi, İstanbul Üniversitesi Sosyal Bilimler Enstitüsü, İstanbul.

Şentürk, A. A. (2016). Osmanlı Şiir Kılavuzu 1, Âb-Azrail, İstanbul: Osmanlı Edebiyatı Araştırmaları Merkezi Yayınları.

Tezcan, N. (2001). “Güzele Bir Şehrengizden Bakış”, Türkoloji Dergisi, C.I, (XI), s. 161-194

Turan L. (1998). "Yenişehirli Avnî Bey Dîvânı’nın Tahlili (Tenkitli Metin) Encümen-i Şu'arâ ve Batı Tesirinde Gelişen Türk Edebiyatına Geçiş”, Doktora Tezi, Atatürk Üniversitesi Sosyal Bilimler Enstitüsü, s. 581-586.

Turan, L. (2011). "Defterdâr-zâde Ahmed Cemâlî̀nin Siroz Şehrengizi”, İSAM Osmanlı Araştırmaları, S. XXXVII, s. 49-76.

Türk Dil Kurumu (2011). Türkçe Sözlük, Ankara: TDK.

Yazar, İ. (2007). "Dürri'nin Şehregizinden Gümülcine'ye Bakış”, Turkish Studies/Türkoloji Araştırmaları, Volume 2/2 Spring., s. 770-789.

Yazar, İ. (2009). “Dürrînin Moton Şehr-engîzi”, Erdem Dergisi, (55), s. 175-19o. 